\title{
METODE BERMAIN BERPENGARUH TERHADAP KEMAMPUAN LONG PASSING SEPAKBOLA
}

\author{
Vega Soniawan', Roma Irawan ${ }^{2}$
}

\begin{abstract}
Abstrak : Penelitian ini bertujuan untuk mengetahui seberapa besar pengaruh metode bermain terhadap kemampuan long passing sepakbola atlet SSB Muspan Padang. Penelitian ini adalah eksperimental semu. Populasi dalam penelitian ini adalah atlet SSB Muspan Padang yang berjumlah 74 orang. Pengambilan sampel menggunakan teknik purposive sampling berdasarkan karakteristik tertentu dan pertimbangan peneliti sendiri dengan sampel berjumlah 12 orang. Penelitian ini dilakukan selama 6 minggu (18 kali pertemuan), dalam 1 minggu latihan dilaksanakan sebanyak 3 kali pertemuan. Instrumen penelitian yang dipakai adalah tes tendangan lambung. Teknik analisis data dalam penelitian ini menggunakan uji normalis data dan uji T-Test. Hasil pengolahan data dan pengujian hipotesis dalam penelitian ini adalah nilai thitung 6,40 sedangkan tabel sebesar 2,20 dengan taraf signifikan $\alpha=0,05$ dan $\mathrm{n}=12$, maka $\mathbf{t}_{\text {hitung }}>\mathbf{t}_{\text {tabel }}(6,40>2,20)$, terdapat pengaruh yang signifikan dari metode bermain terhadap kemampuan long passing sepakbola atlet SSB Muspan Padang. Penerapan metode bermain dalam proses latihan dapat meningkatkan kemampuan long passing sepakbola.
\end{abstract}

Kata Kunci : Metode bermain, kemampuan long passing sepakbola

\section{PENDAHULUAN}

Pembinaan dan pengembangan olahraga prestasi dilaksanakan dengan memperdayakan perkumpulan olahraga, menumbuh kembangkan sentra pembinaan olahraga yang bersifat nasional dan daerah, dan menyelenggarakan kompetisi sejara berjenjang dan berkelanjutan. Pada saat ini olahraga memberikan pengaruh yang positif dan nyata bagi peningkatan kesehatan masyarakat. Selain itu juga olahraga turut berperan dalam peningkatan kemampuan bangsa dalam melaksanakan sistem pembangunan yang berkelanjutan.

Rendahnya prestasi olahraga yang dicapai oleh para atlet Indonesia pada umumnya, merupakan salah satu akibat kurangnya pembinaan terhadap para atlet pada cabang-cabang olahraga yang ada di Indonesia. Permasalahan mendasar dalam sepakbola nasional adalah kurangnya perhatian tentang pembinaan pada usia dini (grassroots) dan usia remaja

\footnotetext{
${ }^{1}$ Vega Soniawan adalah Dosen Fakultas Ilmu Keolahragaan Universitas Negeri Padang (FIK - UNP)

${ }^{2}$ Roma Irawan adalah Dosen Fakultas Ilmu Keolahragaan Universitas Negeri Padang (FIK - UNP)
} 
(youth). Kunci keberhasilan sepakbola suatu negara apabila memperhatikan pembinaan pada tingkat usia dini dan remaja. Keberhasilan awal seorang pelatih ditentukan oleh kualitas pemain yang dipilihnya. Apabila pelatih mendapatkan pemain-pemain yang baik saat seleksi dan ditunjang pula dengan kepelatihan yang baik, maka prestasi yang dinginkan akan tercapai. Apalagi didukung unsur-usur lainnya seperti sarana dan prasarana yang memadai, keuangan yang cukup, manajemen yang baik. Kualitas kepelatihan sangat menentukan keberhasilan pembinaan sepakbola apalagi pada grassroots dan youths.

Kegiatan olahraga banyak faktor pendukung yang mempengaruhi untuk mendapatkan prestasi, seperti : kondisi fisik, teknik, taktik, dan mental (Sajoto, 1990: 15). Begitu juga dalam olahraga sepakbola di samping memiliki kondisi fisik, teknik, taktik, dan mental yang baik juga diperlukan sekali penguasaan teknik yang baik pula oleh para atletnya, karena tanpa adanya penguasaan teknik yang baik seseorang atlet tidak dapat mewujudkan prestasinya. Bermain sepakbola dengan baik sangat dibutuhkan penguasaan teknik sepakbola, karena kemampuan teknik bermain sangat mendukung seorang pemain dalam bermain sepakbola. Dalam meningkatkan mutu permainan kearah prestasi maka masalah teknik merupakan salah satu syarat menentukan (Darwis, 1999: 49).

SSB Muspan merupakan bagian dari anggota Pengcab Padang. Dalam Prestasinya SSB Muspan Padang belum dapat memperoleh prestasi di kota Padang dari sekian banyak kompetisi yang telah diikuti, seperti Piala Prihatin, Piala Danone, dan terakhir seleksi Akademi Nusantara yang didalamnya belum ada pemain SSB Padang yang terpilih. Program latihan yang telah dibuat oleh pelatih telah dilaksanakan sesuai dengan apa yang diberikan akan tetapi peningkatan permainan belum banyak dirasakan. Hal ini terlihat terutama saat pemain sedang melakukan serangan balik, pemain terlihat lamban dalam melakukan penyerangan dan kurang melakukan long passing sehingga tidak mampu merubah arah permainan dengan long passing sesuai arah yang diinginkan.

Teknik long passing merupakan salah satu teknik dasar yang harus dimiliki seorang atlet dalam permainan sepakbola. Kegunaan dari long passing ini yaitu untuk melakukan umpan dengan jarak jauh yang berguna dalam penyusunan serangan dan menciptakan peluang terciptanya gol dalam suatu pertandingan. Bila kemampuan long passing yang bagus sudah dimiliki maka kesempatan untuk memenangkan pertandingan akan semakin besar. Schmid (2004: 15) menyatakan teknik long passing ini sangat berguna sekali untuk 
merubah permainan dari suatu daerah ke daerah lain dengan cepat. Menurut Mielke (2007: 19) menyatakan bahwa apabila bisa menggerakkan bola dengan lebih cepat lagi sehingga dapat menciptakan ruang terbuka yang lebih besar dan berpeluang melakukan tendangan yang lebih banyak jika dapat melakukan long passing dengan keterampilan dan ketepatan yang tinggi.

Berdasarkan pemikiran tersebut, peneliti berpendapat bahwa penggunaan bentuk latihan yang tepat diharapkan dapat mengatasi tidak meningkatnya kemampuan long passing atlet SSB Muspan Padang. Bentuk latihan yang dapat digunakan dalam peningkatan kemampuan long passing adalah metode bermain (fundamental) yang mengarah dan mengacu untuk meningkatkan kemampuan long passing sepakbola atlet. Dalam mengatasi permasalahan di atas, pelatih harus menciptakan suasana latihan yang mengaktifkan atlet sehingga menguasai long passing dengan baik. Menurut Suharno (1993: 18), metode adalah suatu bentuk atau cara yang digunakan untuk memberikan tujuan yang akan dicapai.

Menurut Gordon (2009: 94) metode latihan merupakan suatu cara atau strategi yang membantu seseorang atau pemain untuk mencapai suatu tujuan yang diharapkan. "The level of specific adaptation will be low and will only become more specific as the athlete develops and is introduced to more specialized training methods. Metode latihan merupakan yang paling tepat dalam peningkatan teknik seorang pemain sepakbola, menurut Harsono (1986: 27) "Metode latihan dalam olahraga adalah suatu proses rangsangan dimana kegiatan atau aktivitas ini akan mengakibatkan kepada suatu penyesuaian organisme".

Menurut Syafrudin (1999: 86) "Metode latihan dalam olahraga adalah suatu proses rangsangan dimana kegiatan atau aktivitas ini akan mengakibatkan kepada suatu penyesuaian organisme". Metode latihan merupakan cara yang dipergunakan untuk melatih teknik-teknik olahraga serta keterampilan suatu cabang olahraga tertentu. Setiap pelatih dan pembina olahraga dalam memberikan latihan harus menggunakan metode latihan, karena dengan menggunakan metode latihan, maka latihan dapat direncanakan dan dilaksanakan sesuai dengan tujuan dan kondisi yang ada.

Oleh sebab itu, pelatih membutuhkan sebuah metode latihan yang bisa mengaktifkan atletnya dalam penguasaan long passing, maka metode bermain yang dijadikan program 
dalam penelitian ini. Makna dari kata bermain oleh masyarakat luas telah ditafsirkan bermacam-macam, dan kadang-kadang makna tersebut berbeda-beda. menurut Soemitro dalam Jonni (2010: 27) bermain adalah dorongan langsung dari dalam diri setiap individu dimana bila dilakukan oleh anak-anak hal itu merupakan pekerjaan bagi mereka, sedangkan bagi orang dewasa hal itu merupakan suatu kegembiraan. Menurut Koger (2007: 14) "Metode bermain adalah metode yang mengajarkan suatu keterampilan psikomotorik dengan cara peragaan teknik kemudian mempraktikkannya dalam proses permainan”. Berdasarkan pendapat tersebut disimpulkan bahwa pada permasalahan teknik long passing sepakbola dengan metode bermain sebagai program untuk perbaikannya.

\section{METODE}

Penelitian ini adalah eksperimental semu. Peneltian ini bertujuan untuk mengetahui pengaruh metode bermain terhadap kemampuan long passing sepakbola atlet SSB Muspan Padang. Pengambilan sampel dilakukan secara Purposive Sampling. "Teknik pengambilan sampel ini berdasarkan pertimbangan peneliti sendiri” Sugiyono (2011: 300). Pada kelompok usia U13-U16 sudah bisa dilakukan penelitian, karena perkembangan secara kondisi fisik dan penguasaan dalam teknik bermain sepakbola mereka cukup bagus dan mulai berkembang. Berdasarkan pertimbangan peneliti bahwa jumlah atlet dengan kelompok U13-U16 dengan jumlah 24 orang yang mengikuti latihan di SSB Muspan Padang.

Instrument tes yang digunakan dalam penelitian ini adalah "Test Tendangan Lambung”, M. Barrow (1971: 310). Pelaksanaan tes tendangan lambung yaitu pemain melakukan tendangan lambung ke dalam lapangan tes dari bola diam yang berada pada garis tepi. Untuk mengukur hasil tendangan jauh dimulai dari batas bola ditendang sampai bola jatuh pertama kali di tanah lalu diukur dalam satuan meter. Dalam tes ini bola yang keluar dari lapangan tes tidak dihitung atau gagal. Tes tendangan lambung ini pemain diberikan kesempatan tiga kali dan kemudian diambil nilai yang terbaik.

Pendeskripsian data dan pengujian hipotesis dalam penenlitian ini dapat diolah dengan memakai statistik deskipsif dan inferensial dengan rumus uji t sampel terikat. Teknik analisis data dengan uji normalitas data dan uji homogenitas data dilakukan 
sebelum data diolah. Uji normalitas bertujuan untuk mengetahui apakah kelompok sampel berasal dari yang berdistribusi normal atau tidak.

\section{HASIL}

Hasil penelitian digambarkan sesuai dengan tujuan dan hipotesis yang diajukan sebelumnya. Gambaran deskriptif data pre test dan post test metode bermain dalam penelitian ini dapat dilihat sebagai berikut :

\begin{tabular}{|c|c|c|c|c|}
\hline No. & Kelompok & Statistik & Tes Awal & Tes Akhir \\
\hline \multirow{3}{*}{1} & & Mean & 37,98 & 40,51 \\
& Metode & Std. Dev & 1,51 & 1,40 \\
& Bermain & Min & 37,35 & 37,97 \\
& & Max & 42,54 & 42,83 \\
\hline
\end{tabular}

Berdasarkan dari tabel di atas, data tes awal kelompok metode bermain didapat nilai mean 37,98, standar deviasi 1,51, nilai minimum 37,35, dan maksimum 42,54. sedangkan data untuk tes akhir untuk kelompok metode bermain mean 40,51, standar deviasi 1,40, nilai minimum 37,97, dan maksimum 42,83. Artinya terdapat peningkatan dari nilai akhir terhadap metode bermain setelah diberi perlakuan.

\section{a. Uji Normalitas}

Pengujian normalitas distribusi frekuensi dilakukan dengan uji liliefors. Hasil pengujian normalitas pre test dan post test dari metode bermain adalah :

1. Hasil pengujian untuk pre test metode bermain, skor $\mathrm{L}_{0}=0,0778$ dengan $\mathrm{n}=12$, sedangkan $\mathrm{L}_{\text {tab }}$ pada taraf pengujian signifikan $\alpha=0,05$ diperoleh 0,242 yang lebih besar dari Lo sehingga dapat disimpulkan bahwa skor yang diperoleh berdistribusi normal.

2. Hasil pengujian untuk post test metode bermain, skor $\mathrm{L}_{0}=0,0784$ dengan $\mathrm{n}=12$, sedangkan $\mathrm{L}_{\mathrm{tab}}$ pada taraf pengujian signifikan $\alpha=0,05$ diperoleh 0,242 yang lebih besar dari Lo sehingga dapat disimpulkan bahwa skor yang diperoleh berdistribusi normal. 


\section{b. Uji Hipotesis}

Setelah uji persyaratan analisis dilakukan, terdapat variabel penelitian untuk pengujian hipotesis, yaitu terdapat pengaruh yang signifikan metode bermain terhadap kemampuan long passing sepakbola atlet SSB Muspan Padang. Hipotesis ini diuji dengan uji t menggunakan rumus t-test. Hasil analisis hipotesis ini uraiannya terdapat dilampiran dan terangkum pada table dibawah ini :

\begin{tabular}{|c|c|c|c|c|c|}
\hline \multicolumn{2}{|c|}{ Variabel } & N & thitung & t tabel & Keterangan \\
\hline \multirow{2}{*}{$\begin{array}{c}\text { Metode } \\
\text { bermain }\end{array}$} & Pre Test & \multirow{2}{*}{12} & 6,40 & 2,20 & signifikan \\
\cline { 2 - 3 } & Post Test & & & \\
\hline
\end{tabular}

Hasil penghitungan pada tabel di atas menunjukan bahwa pengaruh metode bermain terhadap kemampuan long passing sepakbola sebesar thitung 6,40 sedangkan $\mathbf{t}_{\text {tabel }}$ sebesar 2,20 dengan taraf signifikan $\alpha=0,05$ dan $\mathrm{n}=12$. Berdasarkan hasil tersebut diatas maka thitung $>\mathbf{t}_{\text {tabel }}(6,40>2,20)$ disimpulkan bahwa terdapat pengaruh yang signifikan dengan menggunakan metode bermain terhadap kemampuan long passing atlet SSB Muspan Padang memiliki.

\section{PEMBAHASAN}

Kemampuan long passing merupakan suatu usaha memindahkan bola dengan jauh sesuai dengan sasaran dan dengan ketepatan tinggi serta berguna pada saat melaukukan serangan balik, melewati lawan, dan mengumpan bola dalam usaha mencetak gol ke gawang lawan dengan teknik heading atau menyundul bola. Kemampuan long passing memiliki peranan yang sangat besar dalam sebuah pertandingan yang merupakan salah satu penunjang prestasi sebuah tim, terutama dalam situasi pertandingan yang penting sehingga tim ini bisa menguasai permainan.

Metode bermain adalah metode yang mengajarkan suatu keterampilan psikomotorik dengan cara peragaan teknik kemudian mempraktikkannya dalam proses permainan. Dimana pengajaran latihan gerakan suatu keterampilan dipelajari mulai dari awal gerakan dimana adanya proses bermain, Koger (2007: 14). Dalam proses latihan atau belajar yang 
menggunakan metode bermain, atlet dituntut untuk memecahkan masalah secara sendiri, seperti aktif dan mampu untuk melakukan gerakan-gerkan teknik yang diajarkan.

Dengan menerapkan metode bermain ini, diharapkan pemain SSB Muspan Kota Padang dapat memperbaiki kemampuan long passing. Pemberian latihan dengan metode bermain memberikan dampak positif terhadap pemain SSB untuk meningkatkan kolektivitas permainan serta kekompakan pemain secara keseluruhan dalam sebuah tim serta meningkatkan kemampuan pada saat melakukan serangan balik bisa memposisikan bola terhadap teman dalam satu tim, karena dilatihan metode bermain ini atlet dituntut untuk bermain secara bebas sentuhan atau membatasi sentuhan dengan bola dalam variasi latihan untuk menekankan long passing sepakbola yang baik.

\section{KESIMPULAN}

Berdasarkan analisis data dan pembahasan, maka dapat dikemukakan kesimpulan bahwa, terdapatnya peningkatan dari perlakuan yang diberikan dengan metode bermain, dengan demikian terdapat pengaruh metode bermain terhadap kemampuan long passing atlet secara signifikan terlihat dari hasil yang diperoleh $t_{\text {hitung }}=6,40>\mathrm{t}$ tabel $=2,20$ pada taraf signifikkan $\alpha=0,05$.

Metode latihan dengan menggunakan metode bermain dalam melatih kemampuan long passing sepakbola. Berdasarkan kesimpulan penelitian yang telah dilakukan, ditemukan bahwa latihan dengan menggunakan metode ini menunjukkan peningkatan yang signifikan. Peneliti dapat memberikan saran yang dapat membantu mengatasi masalah yang ditemui dalam pelaksanaan kemampuan long passing sepakbola, yaitu :

a. Bagi pelatih dan guru penjas yang memiliki atlet sepakbola ataupun pemula untuk menggunakan metode bermain dalam meningkatkan kemampuan long passing sepakbola.

b. Didalam proses latihan dengan mempelajari teknik (satu persatu) dianjurkan menggunakan metode latihan untuk meningkatkan kemampuan teknik long passing sepakbola.

\section{DAFTAR RUJUKAN}

Darwis, Ratinus. (1999). Sepakbola: DIP Universitas Negeri Padang. 
Dinata, Marta. (2004). Dasar-Dasar Mengajar Sepakbola. Bandar Lampung: Cerdas Jaya.

Fardi, Adnan. (2005). Hand Out Mata Kuliah Statistik Lanjutan Proyek Pengembangan Hibah Kompetisi A-1. Padang: FIK UNP.

Gifford, Clive. (2007). Keterampilan Sepakbola. Yogyakarta: PT Citra Aji Parama.

Harsono. (1986). Ilmu Coaching. Jakarta: Pusat Ilmu Olahraga KONI Pusat.

Jonni. (2010). Dasar-Dasar Pendidikan Jasmani. Padang: UNP Press.

Koger, Robert. (2007). Larihan Dasar Sepakbola Andal Remaja. Klaten: PT Saka Mitra Kompetensi.

Luxbacher, Joseph A. (2001). Sepakbola: Langkah-Langkah Menuju Sukses. Jakarta: PT Raja Grapindo Persada.

Mielke, Danny. (2007). Dasar-Dasar Sepakbola. Bandung: Pakar Raya.

PSSI. (2010). Peraturan Permainan Sepakbola. Jakarta: PSSI.

Schmid, Barry. (2004). Belajar Sepakbola. Jakarta: Gramedia.

Sugiyono. (2011). Metode Penelitian Pendidikan Pendekatan Kuantitatif, Kualitatif, dan $\boldsymbol{R} \& \boldsymbol{D}$. Bandung: Alfabeta.

Syafruddin. (2011). Ilmu Kepelatihan Olahraga. Padang: UNP Press.

Undang-Undang Sistem Keolahragaan Nasional No 3 (2005). Pembinaan dan Pengembangan Olahraga Prestasi Pasal 27 Ayat: 4. Jakarta: PT Sinar Grafika.

Zein, Muhammad. (2009). Sepakbola Indonesia, Bermain Dalam Aturan. Jakarta: PSSI. 